Acta Universitatis Nicolai Copernici • Pedagogika XXXII/2016

Nauki Humanistyczno-Społeczne • Zeszyt 435

DOI: http://dx.doi.org/10.12775/AUNC_PED.2016.002

Beata Borowska-Beszta

Wydział Nauk Pedagogicznych

Uniwersytet Mikołaja Kopernika

\title{
DZIKIE DZIECI I ODMIENNOŚĆ \\ PSYCHOSOMATYCZNA PROWOKOWANA \\ Rekonstrukcja studium przypadku Wandy Szuman \\ (1955) dotyczącego dwóch chłopców \\ wychowywanych w skrajnej izolacji do 5. roku życia
}

\section{Wprowadzenie}

Droblematyka dzikich dzieci wychowywanych w skrajnej izolacji 1 np. przez dzikie lub domowe zwierzęta, czy więzionych przez rodziców jest znana na świecie i notowana regularnie do współczesności włącznie. Dzikie dzieci (feral children) to wyrażenie zastosowane m.in. przez J. Davida Smitha, Mary Charles McNeil i Edwarda A. Pollowaya na określenie dzieci wychowywanych przez zwierzęta lub dzieci wychowywanych w izolacji. Zdaniem autorów istnieją cztery grupy klasyfikacyjne dzikich dzieci, a wśród nich: dzieci wychowywane przez zwierzęta, dzieci izolowane i wychowywane w warunkach dziczy, dzieci wychowywane w izolacji i uwięzieniu oraz dzieci wychowywane w izolacji i uwięzieniu z ograniczonym kontaktem z ludźmi ${ }^{1}$.

1 M.Ch. McNeil, E.A. Polloway, J.D. Smith, Feral and Isolated Children: Historical Review and Analysis in: Education and Training of the Mentally Retarded, 1984, Vol. 19, No. 1, p. 70. 
Definicja dzikich dzieci oznacza według Grovera Hudsona także „porzucone lub izolowane dzieci, które dorastały pozbawione normalnych warunków nauki języka i nie posługujące się nim"2. Historie dzikich dzieci na świecie są dramatycznym obrazem samowychowania i przetrwania $\mathrm{w}$ skrajnej deprywacji. Problemom tym szeroko poświęcają uwagę m.in.: B. Bettleheim ${ }^{3}$, R. Scheerenberger ${ }^{4}$ J., D. Smith, M., Charles McNeil i E., A. Polloway ${ }^{5}$ oraz Douglas K. Candland 6 . Warto nadmienić, że kategorii dzikości i zdziczeniu, jako kontekstowi edukacji, poświęcił monografię A. Nalaskowski ${ }^{7}$ który nie ujął co prawda w kontekstach edukacji tak rzadkiej formy zdziczenia i dzikości jak wychowywanie w skrajnej izolacji, lecz opisał procesy sprzyjające samemu zdziczeniu w tle współczesnej edukacji.

D. Smith, M., Charles McNeil i E., A. Polloway ${ }^{8}$ piszą, że obecność dzikich dzieci w kulturach na świecie jest notowana od około 500 lat. Jednym z bardziej znanych przypadków dzikich dzieci, który przyczynił się do powstania pedagogiki specjalnej jako subdyscypliny naukowej był odnaleziony w ok. 12 roku życia chłopiec żyjący w izolacji w lasach, w południowym regionie Francji, Aveyron, w pobliżu miejscowości Saint Sernin, nad rzeką Rance. Od pojmania chłopca w 1800 r. i pierwszego gestu wobec dzikiego 12-latka, (nazwanego później Victorem) wykonanego przez francuskiego lekarza Jeana-Marca G. Itarda, rozpoczęły się planowe i systematyczne działania reedukacyjne i rewalidacyjne. J.M.G. Itard zamierzał przywrócić Vic-

2 G. Hudson, Essential Introductory Linguistics. Oxford 2000, p. 175.

3 B. Bettelheim, Feral children and autistic children. In: American Journal of Sociology, 44, pp. 455-467.

${ }^{4}$ R.C. Scheerenberger, A history of mental retardation, Baltimore 1983.

5 M. Charles McNeil, E.A. Polloway, J.D. Smith, Feral and Isolated Children: Historical Review and Analysis in: Education and Training of the Mentally Retarded, 1984, Vol. 19, No. 1, p. 70-79.

6 D.K. Candland, Feral Children and Clever Animals Reflections on Human Nature, Oxford 1993.

7 A. Nalaskowski, Dzikość i zdziczenie jako kontekst edukacji, Kraków 2006.

8 M.Ch. McNeil, E.A. Polloway, J.D. Smith, Feral and Isolated Children: Historical Review and Analysis in: Education and Training of the Mentally Retarded, 1984, Vol. 19, No. 1, p. 70-79. 
tora społeczeństwu ${ }^{9}$ i niejako odwrócić proces zdziczenia. Inne dzikie dzieci, które bywały porzucane przez rodziców lub przetrzymywane $\mathrm{w}$ nieludzkich warunkach głodzenia i izolacji, odnajdowano systematycznie $\mathrm{w}$ różnych regionach świata. Ostatni zarejestrowany przypadek dotyczy Oksany Malayi, nastolatki odnalezionej na Ukrainie w 1991 r., dziewczynki wychowywanej przez psy. David K. Douglas w swej obszernej monografii poświęconej dzikim dzieciom stawia m.in. następujące pytanie: „gdy znajdujemy dzisiaj dzikie dziecko, jakie pytania postawimy odnośnie jego natury?"10. Analogiczne pytania stawiała w 1955 r. polska pedagog i andragog specjalna Wanda Szuman (1890-1994), gdy rozpoczęła pierwszą pracę naukowo-badawczą i opiekuńczo-rewalidacyjną wobec dwóch polskich chłopców wychowywanych w skrajnej izolacji do 5. r. życia.

Dzikie dzieci jako kategoria analityczna są przez mnie rozumiane jako odmienność psychosomatyczna prowokowana, wpisująca się do różnorodnych form odmienności psychosomatycznej (niepełnosprawności) człowieka ${ }^{11}$. Odróżnia ją od odmienności psychosomatycznej (niepełnosprawności) uwarunkowanej np. warunkami genetycznymi i czynnikami endogennymi to, że została sprowokowana zewnętrznie, egzogennie, opresyjnymi i degradującymi warunkami środowiskowymi czy kulturowymi. Nie ma niestety pewności odnośnie potencjału pierwotnego chłopców, podmiotów badań i wsparcia W. Szuman ani odnośnie jakości ich przypuszczalnego stanu funkcjonowania, gdyby wychowywali się w godnych i bezpiecznych warunkach. Można natomiast być pewnym, że nie doszłoby do procesu sprowokowania ich wtórnej odmienności psychosomatycznej (niepełnosprawności).

Poniższy artykuł jest rekonstrukcją i reinterpretacją unikatowych badań jakościowych toruńskiej pedagog i andragog specjalnej - W. Szuman nad rozwojem i funkcjonowaniem dwóch polskich chłopców,

9 D. Deutsch-Smith, Pedagogika specjalna, t. 1, Warszawa 2009.

10 D.K. Candland, Feral Children and Clever Animals Reflections on Human Nature, Oxford 1993, s. 3.

11 B. Borowska-Beszta (red.), Oswajanie odmienności psychosomatycznej. 11 Raportów z polskich jakościowych badań pedagogicznych i andragogicznych, Saarbrücken 2016. 
wpisujących się w ramy naukowych definicji dzikich dzieci. Studium przypadku i badania w działaniu wykonane przez autorkę są ilustracją dzieci więzionych przez rodziców, zamieszkujących w okolicach Włocławka w Polsce i odebranych im w 1954 r. Analizując projekt z perspektywy epistemologicznej, W. Szuman zrealizowała pełne pedagogiczne, wieloletnie badania w działaniu (badania jakościowe, obserwację uczestniczącą). De facto na skutek podjętych decyzji pedagogicznych i działań badawczych W. Szuman dokonała zmian w życiu podmiotów jej badań, zapewniając opiekę i wsparcie do osiągnięcia przez nich dorosłości. Chcę podkreślić, że analizowany projekt badawczy W. Szuman został nazwany przez autorkę zgodnie z realizowaną techniką obserwacją, bez doprecyzowania szczegółowych założeń filozoficznych projektu oraz metodologicznych, w tym wskazania typu obserwacji. Te elementy strukturalne założeń teoretycznych prowadzonych badań można jednakże zrekonstruować na podstawie danych z opublikowanego przez autorkę raportu oraz innych dokumentów wizualnych z prywatnego archiwum autorki niniejszego artykułu. Badania W. Szuman można zatem nazwać partycypacyjnymi badaniami w działaniu opartymi na obserwacji uczestniczącej.

Omawiany projekt badawczy był zapoczątkowany w minionym systemie ustrojowo-politycznym w 1955 r., w czasach PRL-u w Polsce, gdy pozytywizm był dominującym paradygmatem badawczym w dyscyplinie nauk społecznych, pedagogice i jej subdyscyplinie - pedagogice specjalnej. Fakt ten nie jest bez znaczenia dla dookreślenia stanu i momentu ewolucji badań jakościowych w polskiej pedagogice, pedagogice specjalnej i andragogice specjalnej, w których wstępny raport z trzyletnich badań W. Szuman stanowi rzadki i oryginalny wkład. Również z tego powodu rekonstruuję wskazane mało znane i pionierskie pedagogiczne badania w działaniu oraz deskrypcje rzadko spotykanej formy zdziczenia rodzinnej rzeczywistości wychowawczej, dotyczącej problemu dzieci więzionych i skrajnie zaniedbanych. Badania W. Szuman przywołuję na tle kontekstów ontologii i epistemologii jej projektu badawczego ze wskazaniem analiz autorki, ich rekonstrukcji oraz moich reinterpretacji. Zdając sobie sprawę z czasu realizacji projektu badawczego i odmiennego języka pedagogów cytowanych przez 
W. Szuman, dostrzegam również konieczność skomentowania problemu retoryki badań ujawnionej w tekście.

Artykuł poprzedza przegląd elementów biografii naukowo-badawczej W. Szuman z pominięciem obszernych danych dotyczących praktyki pedagogicznej badaczki oraz obejmuje kolejno wiele odniesień do tekstu źródłowego autorki i deskrypcji fragmentu całego wieloletniego projektu badawczego. Bogaty pedagogiczny życiorys W. Szuman został uprzednio opisany $\mathrm{w}$ polskiej literaturze naukowej $\mathrm{w}$ monografiach, publikacjach pod redakcją lub artykułach naukowych, m.in. C. Łapicza $^{12}$, A. Wojciechowskiego ${ }^{13}$, C. Kosakowskiego ${ }^{14}$, A. Wałęgi ${ }^{15}$, A. Prokopiak-Lewandowskiej ${ }^{16}$, B. Borowskiej-Beszty ${ }^{17,18}$, J. A. Malinowskiego ${ }^{19} \mathrm{i}$ in. Artykuł niniejszy pomija również dane $\mathrm{z}$ omawianego raportu, związane stricte z pracą terapeutyczną i pedagogiczną nad rozwojem i postępami chłopców w Pogotowiu Opiekuńczym w Toruniu, dając priorytet perspektywie badawczej. W poniższym artykule kategorie dzikość i zdziczenie, jakimi opisywano dzieci po odebraniu rodzicom, postrzegam, jako kategorie wpisujące się semantycznie w odmienność psychosomatyczną (niepełnosprawność) prowokowaną na drodze działania kompleksu niekorzystnych czynników wychowawczych, opartych na wielostronnej deprywacji w środowisku rodzinnym na tle kultury.

12 Cz. Łapicz (red.), Wanda Szuman: Historia jednego życia, Toruń 1997.

13 A. Wojciechowski, Obecność. Zebrane teksty, Torun 2001.

14 Cz. Kosakowski, Węzłowe problemy pedagogiki specjalnej, Toruń 2003.

15 A. Wałęga, Życie i działalność Wandy Szuman (1890-1994), Toruń 2005.

16 A. Prokopiak-Lewandowska, Działalność Wandy Szuman na rzecz osób niewidomych - wybrane aspekty, „Paedagogia Christiana” 1(19) 2007, s. 167-180.

17 B. Borowska-Beszta (red.), Wanda Szuman - pedagog i andragog specjalny - szkice do portretu, Radom 2009.

18 B. Borowska-Beszta, „Idź i zrób coś: Wanda Szuman (1890-1994): polska andragog specjalna, w: Seniorki polskiej andragogiki, pod red. A. Frąckowiak, Radom 2011, s. 69-96.

19 J.A. Malinowski, Działalność Wandy Szuman: ponadczasowe przesłanie dla pracy socjalnej, w: Kobiety $w$ pracy socjalnej, pod. red. A. Kotlarskiej-Michalskiej, Poznań 2013, s. 179-189. 


\section{Wanda Szuman - badaczka terenowa}

Wanda Szuman (1890-1994), toruńska pedagog i andragog specjalna, profesjonalnie przygotowywała się do pracy pedagogicznej oraz badawczej w latach 1921-1923, podczas studiów w dwuletnim Państwowym Instytucie Pedagogicznym [później: Państwowym Instytucie Pedagogiki Specjalnej, a obecnie Akademii Pedagogiki Specjalnej] w Warszawie. Ponadto, podczas pobytu w terenie w czasie zagranicznych staży naukowych w Belgii, Francji i Anglii w latach 1924-1925, finansowanych przez Ministerstwo Oświaty, w celu poznania pracy wychowawców w domach dla sierot. Związki badaczki ze środowiskiem akademickim polskich pedagogów specjalnych można dostrzec w wieloletniej współpracy emerytowanej już W. Szuman z prof. dr hab. Czesławem Kosakowskim i dr art. kw. II st. Andrzejem Wojciechowskim z ówczesnego Wydziału Humanistycznego Uniwersytetu Mikołaja Kopernika w Toruniu. Mając bogate doświadczenie terenowe i praktyczne, W. Szuman, jeszcze mająca lat ok. 80, była zapraszana do wygłaszania wykładów o niepełnosprawności w latach 70-tych XX w. W latach 80-tych współpracowała z A. Wojciechowskim i podejmowała pierwsze ważne kroki w kierunku inkluzji społecznej niepełnosprawnych artystów z całej Polski w społeczności akademickiej UMK. Współorganizowała wystawy prac niepełnosprawnych artystów w Bibliotece Głównej UMK oraz umożliwiła od 1978 r. zaistnienie na zagranicznym forum sztuki w Vaduz, w Lichtensteinie polskim artystom z amputacjami lub niedowładem kończyn, malującym ustami lub nogami. W. Szuman zmarła w Toruniu w 1994 r. po 104 latach aktywnego życia, pracy pedagogicznej oraz terenowej ${ }^{20}$.

Toruńskimi kontynuatorami jej myśli pedagogicznej i/lub badawczej, podejmującymi badania lub działania w różnych problemach pedagogiki specjalnej są profesorowie: C. Kosakowski (pedagogika specjalna, podmiotowość osób z niepełnosprawnością), A. Wojciechowski

20 B. Borowska-Beszta (red.), Wanda Szuman - pedagog i andragog specjalny - szkice do portretu, Radom 2009. 
(twórczość artystyczna osób z niepełnosprawnością), J. Binnebesel (opieka pozamedyczna nad dziećmi przewlekle chorymi, hospitalizowanymi). Ponadto, mgr B. Momot, pedagog Pracowni Rozwijania Twórczości Osób Niepełnosprawnych im. Wandy Szuman (praktyka codziennego wsparcia osób z niepełnosprawnością) oraz autorka niniejszego artykułu - B. Borowska-Beszta (andragogika specjalna, metodologia jakościowa, badania terenowe).

W. Szuman, znana szczególnie torunianom, zrealizowała analizowane, interesujące badania w 1955 r. na zlecenie Komitetu Nauk Pedagogicznych, Polskiej Akademii Nauk ${ }^{21}$. Były to, jak wspomniałam uprzednio, unikatowe z dzisiejszej perspektywy pedagogiczne badania w działaniu, obserwacja uczestnicząca i w konsekwencji osobiste towarzyszenie w rozwoju dwóm chłopcom wychowującym się do ok. 4. i 5. roku życia w skrajnej izolacji. W. Szuman poświęciła obu chłopcom długoletnią pracę wychowawczą, rewalidacyjną zainicjowaną badaniami w działaniu. Autorka pisze „brałam np.: osobiście udział w obserwacji, a potem w wychowaniu dwóch chłopców z Włocławka, którzy na skutek całkowitej izolacji w rodzinie i nieprawdopodobnie prymitywnych warunkach bytu, stali na stopniu rozwoju zwierząt, wydobywali z siebie ryki i nie umieli wykonywać najprostszych czynności fizycznych. Przypadek może drastyczny i nietypowy. Miło mi jednak powiedzieć, że obaj chłopcy, dziś 19-20-letni ukończyli szkołę podstawową specjalną, odbyli dwuletnią praktykę w szkole ogrodniczej i dziś z pożytkiem pracują w tym zawodzie"22. W. Szuman, mająca 65 lat, została w 1955 r. opiekunem prawnym chłopców i prowadziła ich, jako pedagog, do dorosłości, czuwając nad ich rozwojem w placówkach opiekuńczych i szkołach, gdzie edukację rozpoczęli w $1957 \mathrm{r}$.

21 W. Szuman, Obraz rozwoju dwóch chłopców ze skrajnej izolacji (bezpośrednio po zabraniu ich z domu), „Szkoła specjalna” 1958, z. 3, s. 241-254.

22 K. Mazurkiewicz, Poemat optymistyczny - rozmowa z dr Wanda Szuman, „Pomorze”, 17 (335) 1965. 


\section{Rekonstrukcja założeń studium przypadku W. Szuman (1955)}

To, co wyróżniało inicjowane badawcze prace terenowe W. Szuman, było pierwotnym impulsem niesienia pomocy dzieciom, dorosłym z niepełnosprawnością lub znajdującym się w trudnych sytuacjach życiowych oraz chęć wprowadzania w ich życie zmian na lepsze. Mottem W. Szuman było powiedzenie „idź i zrób coś”23, co oznaczało imperatyw i chęć wdrożenia zmian, jakie W. Szuman postrzegała za konieczne wobec wielości problemów pedagogicznych dotyczących dzieci, młodzieży i dorosłych. Temu mottu była wierna przypuszczalnie od czasu praktyk na studiach w Warszawie, tj. w latach 1921-1923. Analizowany w niniejszym artykule projekt badawczy (studium przypadku) odnosi się do zbadania i opisania funkcjonowania i rozwoju chłopców, Wojtka i Leszka ${ }^{24}$ na przestrzeni trzech lat (1955-1958). Projekt został zainicjowany formalnie z oficjalnym nadaniem mu 11.01.1955 r. statusu projektu naukowego przez Komitetu Nauk Pedagogicznych PAN.

W. Szuman ${ }^{25}$ wspomina przy tym, że chłopcy, których postanowiła obserwować i zarazem kształtować ich rozwój, nie byli jedynym znanym jej w Polsce przypadkiem dzieci wychowywanych w skrajnej izolacji. Autorka pisze: „niestety fakty podobne nie są przecież tak odosobnione, jak można było sądzić na początku. Sama poznałam już 6 podobnych spraw izolacji dzieci, z tego w 5 wypadkach, chowanie dzieci wśród zwierząt podwórzowych (w różnych częściach naszego kraju). To są zagadnienia, na które należy spojrzeć otwarcie i wyciągnąć z nich odpowiednie konsekwencje" 26 . W. Szuman opublikowała w 1958 r. raport ze studium przypadku i wstępnej obserwacji, napisanej po trzech latach od zainicjowania przez nią czynności badawczych i wspierających. Raport nosi tytuł: Obraz rozwoju dwóch chłopców ze

23 B. Borowska-Beszta, „Idź i zrób coś: Wanda Szuman (1890-1994): polska andragog specjalna, w: Seniorki polskiej andragogiki, pod red. A. Frąckowiak, Radom 2011, s. 69-96.

24 W. Szuman, dz. cyt., s. 241.

25 Tamże.

26 Tamże, s. 253. 
skrajnej izolacji (bezpośrednio po zabraniu ich z domu). Tekst ukazał się w polskim czasopiśmie naukowym „Szkoła Specjalna” w 1958 roku (nr 3, s. 241-251). Wanda Szuman pisze w pierwszych wierszach artykułu: „do Okręgowego Pogotowia Opiekuńczego w Toruniu przywieziono w roku 1954 dwóch chłopców w wieku około 5 lat w stanie ciężkiego wyczerpania. Dzieci te były trzymane przez rodziców stale w zamknięciu i ciemności. Nie umiały chodzić ani mówić. Wyglądem swym i zachowaniem oraz głosem przypominały zwierzęta"27.

\section{Próba celowa}

\section{„Dzikusy z lasu”}

Chłopcy Wojtek i Leszek, po odebraniu ich, wyrokiem sądu, rodzicom w dn. 27.101954 r., trafili najpierw do Powiatowego Wydziału Oświaty i potem do Domu Dziecka w Chełmnie. Pierwsza ich podróż w życiu została również odnotowana przez W. Szuman jako trudniejsza dla opiekunów, ponieważ dzieci były bardzo zaniedbane. Badaczka pisze: „prawie nagie, miały ledwie łachmany na sobie, ani czapki, ani beretu, brudne koszule, bez majtek, palta jak gdyby z gnojownika wyciągnięte, każda pończocha inna, na główkach brud niejako wrośnięty"28. Natomiast do Pogotowia Opiekuńczego w Toruniu przyjechały z Domu Dziecka umyte i czysto ubrane. Ich zachowanie oraz wygląd wzbudzały różne refleksje i komentarze oraz tworzone charakterystyki. Dzieci „robiły wrażenie zwierząt i to bardzo opuszczonych, zaniedbanych”29. Psycholog, zastępujący opiekunkę mgr Różycki opisał chłopców następująco „chłopcy wydawali tylko dźwięki, jak gdyby ö. Chwytali z biurka wszystkie i dostępne przedmioty świecące"30. Dyżurna wychowawczyni pogotowia opisała nowych podopiecznych, Wojtka i Leszka, następująco: „takich potworków w życiu nie widziałam, a przecież byłam wychowawczynią w Zakładzie dla idiotów w Świeciu. Twarze mie-

\footnotetext{
27 Tamże, s. 241.

28 Tamże, s. 243.

29 Tamże, s. 244.

30 Tamże.
} 
li jak gdyby nieforemne. Wojtek miał nogi i ręce krzywe"31. Kierowniczka pogotowia widziała dzieci przelotnie, opisała je następująco: „dzieci w dniu ich przybycia zrobiły na mnie wrażenie dzikich zwierząt"32, co wyjaśniła dalej: „bo to wyglądało, jak gdyby nigdy ludzi nie widzieli, jak gdyby ludzie byli dla nich czymś nowym”. „Przy stoliku w jadalni, jeden z chłopców, nie pamiętam który, czy się przestraszył czegoś, czy zaszło co innego (w jadalni byli wtedy również starsi chłopcy), bo wstał i zaczął pełzać z płaczem i dzikim krzykiem. To były jak gdyby żabie ruchy, nóżki rozszerzone po żabiemu, tył trzymał wyżej od przodu"33. Lekarka, dr Krippendorf, scharakteryzowała chłopców w następujący sposób: „chłopcy robili wrażenie dzikusów z lasu, spojrzenie mieli mało przytomne, dźwięki nieludzkie, uciekali, kryli się pod łóżka"34.

W. Szuman wskazała, że dane medyczne zawarte w kartach zdrowia po zbadaniu dzieci wskazywały, że ich narządy wewnętrzne były bez zmian chorobowych, miały anemię, powiększone migdały oraz gruczoły szyjne, niedorozwój umysłowy oraz mutyzm. Dodatkowo u Wojtka zdiagnozowano zaawansowaną krzywicę i zniekształcenie kończyn w stopniu znacznym. Stomatolog stwierdził, że dzieci mają jedynie pieńki zębów zamiast zębów. Inne interesujące charakterystyki zachowania dzieci wskazały higienistka i krawcowa. Kobiety zauważyły, że dzieci „raczej łykały niż gryzły” posiłki oraz „że były strasznie łakome, z talerza jadły bezpośrednio ustami, nie wiedziały co zrobić z łyżką, nic nie mówiły i ciągle wydawały jakieś dźwięki i piski. Nie odróżniało się żadnego słowa, w ogóle głosek"35. S. Kasprukowa, główna wychowawczyni Pogotowia Opiekuńczego, mająca pod opieką Wojtka i Leszka, wskazała w ich zachowaniu i sposobie poruszania się następujące cechy: „brzmiał tylko jeden ryk, dzieci posuwały się jedynie bokiem, na pośladku. Gdy jeden się poruszył, drugi za nim. Początkowo byłam zupełnie bezradna, nie wiedziałam co robić, nie zaistniał bowiem w mojej pracy żaden fakt podobny. Dzieci co chwila

\footnotetext{
31 Tamże.

32 Tamże.

33 Tamże.

34 Tamże, s. 245.

35 Tamże.
} 
się załatwiały. Bieliznę osobistą i pościelową trzeba było wciąż zmieniać, czasem co parę minut" ${ }^{36}$. Inna wychowawczyni, której wypowiedzi i charakterystykę przytacza W. Szuman, p. Kuryłko mówi: „często i w dzień zmieniałyśmy im ubrania, dlatego, że 5-6 razy się brudzili i nie było co włożyć, bo jedli i załatwiali się"37.

Wśród innych opisów potencjału funkcjonalnego i dysfunkcji chłopców były również charakterystyki sporządzone przez główną wychowawczynię, panią S. Kasprukową. Wychowawczyni wskazała, że „gdy sadzaliśmy ich na małym krzesełku dla dzieci przedszkolnych bali się i płakali. Mieliśmy wrażenie, że to doprawdy kaleki. Smoczek trzymali bez ustanku w ustach. Nie można go było zabrać tak ryczeli i wyli. Przez jakiś czas nie chcieli brać od nas nic do jedzenia. Sama się bałam, że umrą z głodu. Dlatego chcieliśmy ich wysłać z Pogotowia. Robiono już odpowiednie starania bo wydawali się idiotami. A na spacerze to było piekło. Tak strasznie ryczeli i wyli i tak kurczowo trzymali ręce na piersiach broniąc się przed rozbieraniem itd. W ogóle nie dali się dotknąć i trzeba było kilku osób, by ich podnieść, przebrać, myć. Płakać mi się chciało. Inne dzieci nie chciały w ogóle wziąć w rękę ich zabrudzonych ubrań, nie chciały pomagać, biły ich. W ogóle każde zbliżenie się powodowało niesamowity ryk. Siedzieli stale odwróceni do ściany lub też jeden patrzał na drugiego, broń Boże by spojrzeli na salę. Przez pierwsze dni niczym się nie bawili"38.

Wychowawczyni wspomina, że bracia bali się małych zabawek i ich zainteresowanie zabawkami było nikłe. „Niczym a niczym, jak gdyby nie widzieli i patrzeć nie umieli. Bali się małych zabawek żabki z gumy, kurki z ceratki, tak, że musiałam je zabrać. Na papier np. czerwony patrzyli, ale nie ruszali go. Umieszczeni razem w oddzielnym pokoju byli spokojniejsi. Gdy posadziłam ich w jednym miejscu i wchodziłam po godzinie, zastawałam ich w tym miejscu w tej samej pozycji. Za dnia byli zupełnie spokojni, rzadko kiedy który płakał. Wojtek, jak się go posadziło, to potrafił godzinami siedzieć na jednym krześle,

\footnotetext{
36 Tamże.

37 Tamże.

38 Tamże.
} 
ręce położył sobie na kolana i tak siedział"39. Odnośnie charakterystyki komunikowania się chłopców W. Szuman pisze, opierając się na spostrzeżeniach sąsiadów chłopców, opiekunek i innych osób, z którymi mieli oni kontakt od 1954 r., po odebraniu rodzicom: „Ob. Królikowska: to był ryk dziki, nie dziecięcy, w każdym razie jak dzikich ludzi. Przypominały mi się ryki z filmu o Tarzanie. Ob. Kuryłko: Początkowo były to tylko krzyki i porozumiewania nieludzkie, miałam wrażenie jakbym była na Tarzanie - eo - podobne do wycia. Jak się do nich mówiło patrzyli oczyma jakby zdziwionymi i tylko ö ö ö mówili. Potem, wydawało nam się, że zaczynają już rozumieć, że wiedzieli, że się do nich mówiło, np. gdy powiedziałam, że są grzeczni, że dostaną cukierek, okazywali zadowolenie" ${ }^{\prime 40}$. Na początku pobytu sposób komunikacji braci był inny i ulegał stopniowym zmianom. Wychowawczyni wskazuje, że „nie mówiły wcześniej nic ani nie rozumiały w ogóle jak się do nich mówiło”41 . „To dziwne brzmienie, obce językowi ludzkiemu, zachowało się nieledwie przez cały rok (1955-1956, przyp. BBB), czyli do czasu, w którym chłopcy już zaczynali mówić króciutkimi zdaniami" ${ }^{42}$. Interesujące jest, że oprócz komunikacji, zwanej przez wychowawczynie i W. Szuman nieludzką i nieartykułowaną, dzieci wykształciły swoisty dla siebie sposób komunikacji, którym porozumiewały się między sobą, natomiast kryły przed świadkami ze świata poza nimi. Badaczka wskazała, że bracia wymawiali „jakby hau, hau, hau, łu, łu, łu, piszczeli jak psiaki, „szczebiot jak u dzikusów”, tylko „e, e, y, y”43.

\footnotetext{
39 Tamże, s. 246.

40 Tamże, s. 249.

41 Tamże.

42 Tamże.

43 Tamże.
} 


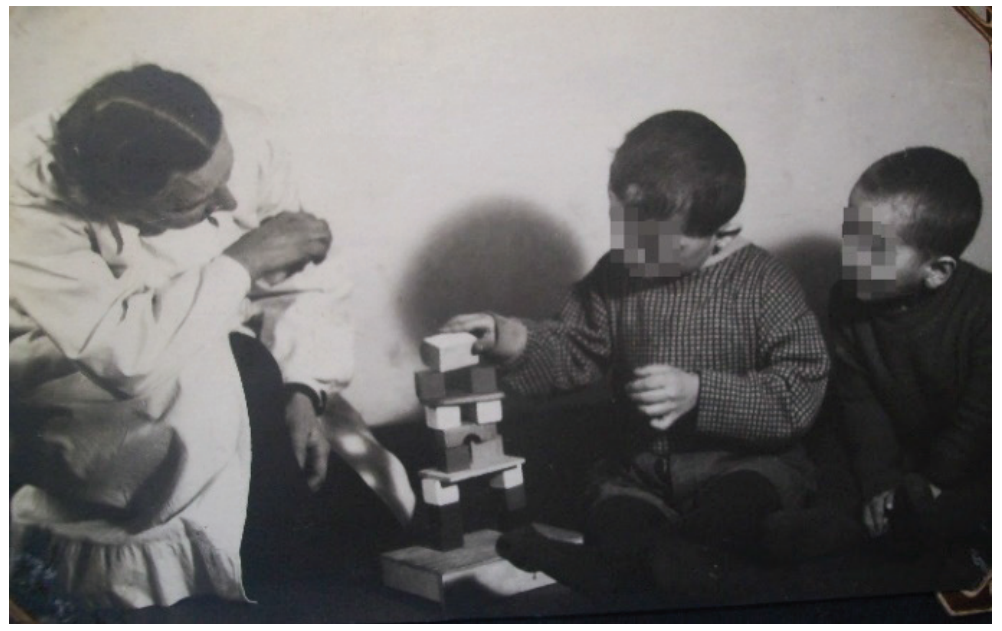

Fot. 1. Wanda Szuman z Wojtkiem i Leszkiem podczas zabawy klockami

Źródło: archiwum prywatne B. Borowska-Beszta; autor fotografii: C. Jarmusz.

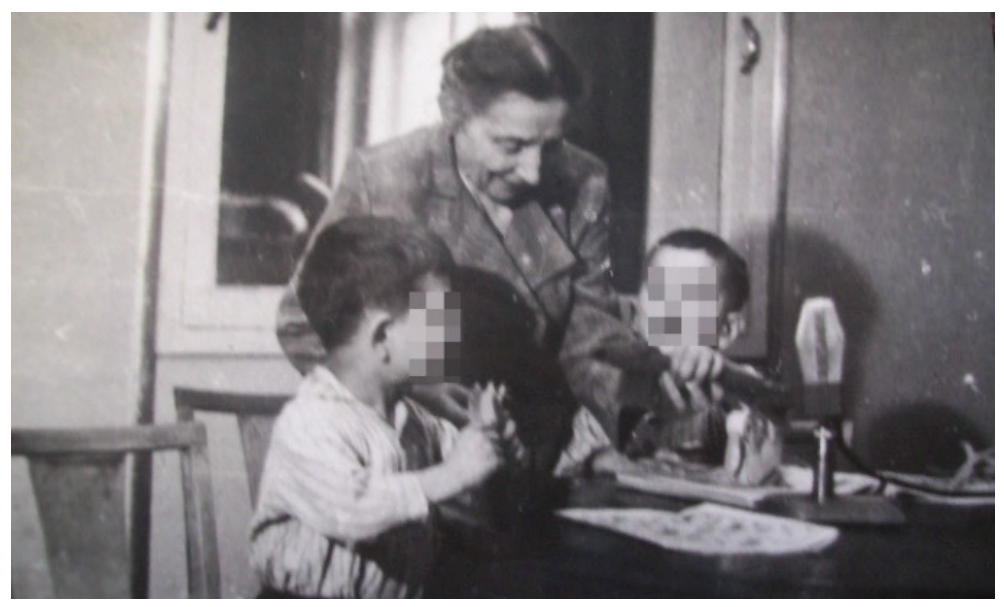

Fot 2. Wanda Szuman z Wojtkiem i Leszkiem podczas ćwiczeń mowy

Źródło: archiwum prywatne B. Borowska-Beszta; Autor fotografii: C. Jarmusz. 


\section{Epistemologia i kroki badawcze}

Gdy badacz rozpoczyna prace nad projektem badawczym, zwykle poprzedza je inspiracjami oraz ugruntowuje na tle formułowania problemu badawczego. W. Szuman o Wojtku i Leszku dowiedziała się przypadkowo, po 11 tygodniach od czasu zabrania dzieci z domu rodzinnego. Chęć badań problemu dzikich dzieci pojawiła się u badaczki, moim zdaniem, na podstawie wcześniej znanych 6 przypadków dzieci wychowywanych w skrajnej izolacji przez rodziców, o czym wspomniała uprzednio i wskazała jako problem ważny, wymagający reakcji. W. Szuman miała wiedzę o analogicznych przypadkach dzieci maltretowanych izolacją przez rodziców. Autorka pisze, że po przywiezieniu chłopców do Pogotowia Opiekuńczego w Toruniu postanowiła obserwować ich rozwój z psychologicznego, społecznego i pedagogicznego punktu widzenia i mieć wpływ na kształtowanie go ${ }^{44}$. Gromadzenie danych było oparte na wizytach badaczki w Pogotowiu Opiekuńczym 2-3 razy w tygodniu i obserwowaniu chłopców. Po sześciu tygodniach obserwacji badaczka przedstawiła problematykę obserwowanych dzieci jako problem badawczy Komitetowi Nauk Pedagogicznych PAN w Warszawie. Uzyskała aprobatę KNP PAN i odtąd prowadziła formalne badania zlecone przez KNP PAN oraz stałe obserwacje chłopców. Prace badawcze, wstępne przyjęte przez W. Szuman, zakładały dokładne zapoznanie się z dokumentacją dotyczącą dzieci oraz historią ich życia $\mathrm{w}$ rodzinie i stanem funkcjonowania. W tym celu W. Szuman wykonała wywiady z: członkami pięciu rodzin zamieszkujących w domu zamieszkania rodziców chłopców (brak pełnej liczby wywiadów), w Pogotowiu Opiekuńczym z personelem i dziećmi (brak liczby wywiadów), w Wydziale Oświaty WRN (brak liczby wywiadów) oraz w Prokuraturze Generalnej w Warszawie, w związku z odwołaniem się rodziców o przywrócenie im praw rodzicielskich (brak liczby wywiadów). Te dane posłużyły jako punkt wyjścia do zbudowania zarysu założeń badawczych projektu i rozpoczęcia przez W. Szuman badań opartych na uczestnictwie.

44 Tamże, s. 241. 
Dane o rzeczywistej sytuacji obu chłopców oraz warunkach wychowania w rodzinie uzyskała badaczka z dokumentów urzędowych, danych zastanych, m.in. postanowienia Sądu Okręgowego z dn. 6.10.1954 r. o odebraniu praw rodzicom. Autorka cytuje kluczowe dane $\mathrm{w}$ artykule, z zachowaniem kodowania danych osobowych podmiotów. „Warunki wychowawcze małoletnich dzieci są w najwyższym stopniu opłakane, urągające elementarnym wymogom opieki, pielęgnacji i higieny. Ustalono, że rodzice trzymają swoje dzieci miesiącami w zamknięciu, nie wypuszczają na powietrze; mieszkanie jest w okropny sposób zapuszczone, dzieci są chore na krzywicę, zabiedzone, niedorozwinięte, wyglądem przypominające jakieś zwierzątka, dotąd żadne z nich nie umie mówić, mimo przekroczenia 4-5 roku życia. Rodzice ich trudnią się żebraniną. Ojciec pracować nie chce. Przez swoje karygodne zaniedbania doprowadzili dzieci do wynędznienia i całkowitego opuszczenia. Jest charakterystyczne, że nikogo nie chcą wpuścić do mieszkania, przy czym stanowczo przeciwstawiają się próbom poprawy bytu ich dzieci. Te karygodne zaniedbania nie pozwalają na dalsze sprawowanie przez nich władzy rodzicielskiej i wymagają odizolowania jak najprędzej dzieci, przez umieszczenie ich w domu dziecka. Wobec tego, że dalsze przebywanie dzieci w tej atmosferze i warunkach zagraża ich zdrowiu a nawet życiu, należało niezwłocznie, w trybie zarządzeń tymczasowych, powziąć decyzję co do chwilowego umieszczenia dzieci w Pogotowiu Opiekuńczym”45.

\section{Etyka gromadzenia danych i retoryka raportu z badań}

Dane gromadzone przez W. Szuman do omawianego raportu trwały trzy lata 1955-1958, natomiast cały projekt badania w działaniu trwał 15 lat, do osiągniecia przez chłopców 19-20 roku życia, czyli do roku 1970. W. Szuman miała wtedy 80 lat i przebywała na czynnej, lecz nadal aktywnej zawodowo emeryturze. Prezentowanie danych, opublikowanych w raporcie z 1958 r., odbywało się z zachowaniem kodowania danych osobowych. Autorka zakodowała dane osobowe

45 Tamże, s. 242. 
rodziców chłopców oraz zmieniła imiona dzieciom, dbając o ich anonimowość. W omawianym raporcie ze studium przypadku chłopcy zostali zakodowani jako Wojtek i Leszek. Dodatkowa dokumentacja fotograficzna, należąca do archiwum prywatnego B. Borowskiej-Beszty, przekazana do celów opracowania naukowego przez autora fotografii i wieloletniego współpracownika W. Szuman - C. Jarmusza, wskazuje dodatkowo interesujące fenomeny charakteryzujące dane wizualne w badaniach pedagogicznych, jakie można odnaleźć w analizowanych danych z lat 50-tych. Polegają one na przewadze procesu medykalizacji badań naukowych polskiej pedagogiki specjalnej i dominacji klinicznego sposobu gromadzenia danych. Takie właśnie elementy dostrzegam w studiach przypadków dotyczących podmiotów pedagogiki specjalnej (zob. fot 1.). Fotografie 1., i 2., stanowią przykłady z części prywatnego archiwum zdjęć należącego do autorki artykułu, pochodzących z albumu dokumentującego wizualną historię chłopców po przyjęciu ich w dniu 27.10.1954 r. do Okręgowego Pogotowia Opiekuńczego w Toruniu.

W albumie, na czarno-białych fotografiach opatrzonych opisami, zostali udokumentowani sami chłopcy, bracia z W. Szuman po ich przyjęciu, podczas prowadzonych badań, chłopcy dorastający i przebywający w szkołach. Z punktu widzenia etyki gromadzenia danych chciałabym zwrócić uwagę na dwa wątki, dające wgląd w konceptualizację gromadzenia danych wizualnych $\mathrm{w}$ pedagogicznych badaniach naukowych w latach 50-tych. W. Szuman jako badacz na zdjęciu ma na sobie biały, medyczny fartuch. Natomiast po przyjęciu do Pogotowia, Wojtek (chłopiec z zawansowaną krzywicą) został sfotografowany zupełnie nagi, podtrzymywany przez ręce opiekunki. Sposób fotografowania podmiotów badania $\mathrm{w}$ w/w studium wskazuje na ugruntowanie kliniczne dotyczące koncepcji gromadzenia danych i na medyczno-kliniczne sposoby rozumienia przez badaczkę profesjonalnego sposobu dokumentowania danych z badań. Nie zamieszczam tego zdjęcia w tekście i chcę nadmienić, że nie są to oczywiście jedyne sposoby fotografowania uczestników badań, ponieważ w albumie znajduje się tylko jedna fotografia nagiego dziecka. Analogiczne fotografie można odnaleźć w podręcznikach medycznych z lat 50-tych lub późniejszych, ilustrujących medyczne studia przypadków. 
Jeśli chodzi o język raportu z badań, to cechuje go głos badaczki i głos uczestników z terenu, informatorów. O ile badaczka posługuje się prawidłową polszczyzną i nie stosuje terminologii medycznej, o tyle takie sformułowania są obecne w wypowiedziach osób, od których gromadziła dane do studium przypadku. Nietrudno zauważyć, że pedagodzy i wychowawczynie w latach 1955-1958 posługują się retoryką naukową obecnie anachroniczną i stygmatyzującą, a mianowicie trójstopniową klasyfikacją niepełnosprawności intelektualnej (idiotyzm, debilizm, imbecylizm). Chcę dodać, że czterostopniowa klasyfikacja niepełnosprawności intelektualnej (lekka, umiarkowana, znaczna i głęboka) została wprowadzona w USA przez R. Hebera w 1959 r.

\section{Scena kulturowa - rodzina generacyjna}

\section{Rodzice dziwni}

W analizowanym wstępnym raporcie W. Szuman z 1958 r. znajduje się również wiele uwag poświęconych opisom rodziców oraz ich zachowania czy argumentom, jakimi tłumaczyli własne czynności opiekuńcze i wychowawcze. W. Szuman, jako własne oznaczenie wewnętrznych przekonań i koncepcji wychowania chłopców przez ich rodziców, stosuje przymiotnik dziwne. $\mathrm{Z}$ danych sądowych W. Szuman przytacza również wypowiedź któregoś z rodziców (brak danych którego), o rzekomych reakcjach dzieci na wizyty z zewnątrz grup i służb interweniujących. Autorka cytuje "niech kto sobie będzie a i tak nie otworzę, bo dzieci mogłyby umrzeć, gdyby zobaczyły jakiego człowieka, bo są nerwowo chore i boją się ludzi" ${ }^{\prime 6}$. Autorka wskazuje również w tekście interesujący obraz wyglądu i funkcjonowania obojga rodziców, lecz nie analizuje ani nie podsumowuje ich zachowania w kategoriach klinicznych, pozostając przy określeniu dziwne lub wskazując, w konkluzjach raportu, odnośnie braku umiejętności matki do wychowania dzieci normalnie ${ }^{47}$. Zauważa, że rodzice Wojtka i Leszka, mimo wieku ok. 40 lat, wyglądali na zupełnie wyniszczonych, starych i zaniedba-

\footnotetext{
46 Tamże.

47 Tamże, s. 254.
} 
nych. Utrzymywali się z żebractwa i dorywczych prac, głównie podejmowanych na chwilę, po to, aby mieć argumenty dla odnośnych urzędów na odzyskanie dzieci.

To, co można dostrzec w tekście W. Szuman, lecz nie jest przez autorkę nazwane ani doprecyzowane: rodzice chłopców nie dostrzegali zupełnie, ani nie rozumieli absurdu i irracjonalności własnych działań wychowawczych oraz ich szkodliwości dla zdrowia i życia dzieci. Rodzice nie potrafili zadbać o siebie ani o warunki życia domowego, co W. Szuman wskazała podczas ilustracji mieszkania jako: „okno dwuskrzydłowe zabite deskami i zatkane igliwiem. Był tam jakiś otwór na dach. Umeblowanie stanowiły dwie zbite prycze, na nich trochę łachów, bez pościeli, jeden stół obok kuchenki bez garnków. Ciemnego pokoju nie oświetlała matka nawet lampą naftową, ani lampką oliwną, ale tylko nakładała na „flaszeczkę knot”. Nie wpuściła też do mieszkania monterów, którzy zakładali instalację elektryczną w całym domu „bo w kopalni był wybuch”. Na pytanie sąsiadki czemu ciemno, odpowiedziała „żeby dzieci oczu sobie nie psuły”48. Sąsiedzi powtarzają też swe spostrzeżenia dotyczące brudu, mokrej podłogi i zaduchu w mieszkaniu oraz faktu, że rodzice nie wyprowadzają swoich dzieci nigdy na powietrze, zwłaszcza w ostatnich dwóch latach"49. Sąsiedzi wskazywali również na to, że „dzieci są bite i ciągle płaczą"50. Te opisy wnętrza mieszkania przywodzą, moim zdaniem, na myśl niemal warunki w nazistowskich obozach koncentracyjnych. Argumenty i koncepcje wychowawcze matki, nasycone irracjonalnym lękiem przed elektrycznością oraz obawami przed światłem, które rzekomo psuje dzieciom wzrok, lękiem przed sąsiadami, osobami z zewnątrz przychodzącymi do domu, wnoszą wątpliwości odnośnie stanu funkcjonowania zdrowotnego i psychicznego matki. W. Szuman nie wskazała jednakże żadnych danych na ten temat ani na temat funkcjonowania i zdrowia psychicznego ojca chłopców. Co więcej, W. Szuman pisze nawet o tym, że nie jest jasne czy powinno się winić rodziców za stan ich dzieci. Autorka wskazuje „nie jest dotąd jasne czy w ogóle

\footnotetext{
48 Tamże, s. 241.

49 Tamże.

50 Tamże, s. 254.
} 
można winić w tym wypadku rodziców, którzy działając wręcz fałszywie, czynili to jednak w dobrej wierze, jak na to wskazują poszlaki" ${ }^{51}$. Badaczka zauważyła błędne rozumienie i fałszywe założenia rodziców przyjęte przez nich w procesie wychowania dzieci. Nie wyjaśnia natomiast precyzyjnie źródeł owych błędnych założeń.

Irracjonalne zachowania oraz koncepcje opieki matka chłopców manifestowała, moim zdaniem, podczas opisu (wykonanego przez W. Szuman) jej działań opiekuńczych w zakresie żywienia dzieci oraz jej stosunku do treningu toaletowego. W. Szuman zaznaczyła (rozstrzelonym drukiem) ten wątek następująco: „Sprawa żywienia dzieci przez rodziców przedstawia się szczególnie dziwnie" ${ }^{\prime 2}$. Autorka pisze: „z wypowiedzi kilku sąsiadów wynika, że matka dawała dzieciom jakąś mętną herbatę z budyniem w butelkach ze smoczkiem oraz rozmoczone w ustach kawałki pieczywa. Karmiła dzieci głównie nocą, twierdząc, że „żyją, bo w nocy jedzą” i że lekarz kazał im w nocy pić herbatę i zjadać 2 bułki. Matka przywoziła do Pogotowia kawałki starego pieczywa i pierniki oraz jakąś mętną herbatę w butelkach ze smoczkiem - raz 5 butelek różnej wielkości - i domagała się, by karmiono dzieci nocą"53. W sprawie załatwiania potrzeb fizjologicznych w domu rodzinnym chłopców W. Szuman wskazała dane, świadczące o nierozumieniu przez matkę problematyki dotyczącej jej zadań opiekuńczo-wychowawczych, polegających na nauczeniu dzieci załatwiania potrzeb fizjologicznych w sposób typowy w naszej kulturze Zachodu, czyli do nocniczków lub w toalecie. Autorka pisze „o tym też wspomniała ich sąsiadka, gdy raz jeden wpuściła ich matka do pokoju, dzieci na wpół nagie (było to w kwietniu i zimno) załatwiały się jak stały na podłodze i na środku pokoju. Na zapytanie sąsiadki dlaczego matka ich nie wysadzi, odrzekła: „albo to oni wołają?”54.

Powyższe dane dotyczące tła wychowania omawianego studium przypadku polskich dzikich dzieci wskazują pewne fenomeny warte rozważenia. Na tle szczątkowych opisów rodziców chłopców i ich sty-

\footnotetext{
51 Tamże.

52 Tamże, s. 247.

53 Tamże.

54 Tamże, s. 248.
} 
lu wychowania wyłania się niepełny obraz. Trudno jednak nie zauważyć, że rodzice akceptowali i uważali za prawidłowy stan poważnego zaniedbania samych siebie, własnego mieszkania czy prymitywny oraz irracjonalny styl wychowania dzieci, narażający je na deprywację potrzeb biologicznych, emocjonalnych, informacyjnych, społecznych. Dzieci bowiem były przetrzymywane w domu. Sformułowanie przetrzymywanie dzieci pojawia się w wypowiedziach sąsiadów, odnośnie trzymania dzieci w domu, przypomina rodzaj uwięzienia (confinment) opisywanego w literaturze przedmiotu ${ }^{55}$. Ich rodzicielska postawa wskazywała rodzaj symbiotycznego przywiązania, co znalazło odzwierciedlenie w uporczywych próbach odzyskania dzieci i chęci powrotu oraz utrzymania minionego stanu patologicznej równowagi w rodzinie generacyjnej. Zaburzenia w systemie rodziny po odebraniu dzieci przez sąd wywołały działania i aktywność rodziców, której brakowało, aby zapewnić dzieciom ludzką egzystencję.

Jednocześnie w opisie rodziców odnaleźć można informacje o tym, że potrafili oni komunikować się klarownie językowo i gramatycznie z podmiotami spoza rodziny i kręgu sąsiadów. Ciekawe jest moim zdaniem również to, że rodzice zupełnie racjonalnie i zgodnie z prawidłowymi i logicznymi założeniami potrafili walczyć o odzyskanie dzieci, podejmując konkretne kroki oraz udając się do urzędów państwowych lub bezpośrednio do placówek opiekuńczych. W tych miejscach za pomocą próśb, gróźb lub podstępów dążyli do odzyskania dzieci. Nie ma co prawda danych o tym, czy te własne działania były przez kogoś wspierane i kierowane, czy rodzice samodzielnie je prowadzili. W. Szuman ${ }^{56}$ pisze, że udawali się kilkakrotnie np. do Wojewódzkiego Wydziału Oświaty w Warszawie, bezpośrednio do Bieruta i Komitetu Centralnego PZPR, do Prezesa Rady Ministrów i Prokuratury Generalnej. Próbowali siłą zabrać dzieci z Domu Dziecka, dlatego też w eskorcie dzieci do Pogotowia Opiekuńczego asystowała ówczesna milicja.

55 M.Ch. McNeil, E.A. Polloway, J.D. Smith, Feral and Isolated Children: Historical Review and Analysis, "Education and Training of the Mentally Retarded", 1984, Vol. 19, No. 1, p. 70.

56 W. Szuman, dz. cyt. 


\section{Wyniki i konkluzje - reinterpretacja badań}

Optymistyczną konkluzją o możliwościach wychowania dzikich dzieci więzionych jest stwierdzenie autorów: M., Charles McNeil, E., A. Pollowaya, J., D. Smitha o tym, że w porównaniu z innymi wyodrębnionymi grupami dzikich dzieci, socjalizacja dzieci więzionych uprzednio, przebiega pomyślniej. Autorzy potwierdzają, że bez względu na sposób organizacji środowiska wychowawczego dzikie dzieci wychowywane przez zwierzęta lub w warunkach uwięzienia przez ludzi potrzebują ludzkiej socjalizacji. Autorzy konkludują, że dzikie dzieci nie są ani „szlachetnymi dzikusami” Jeana-Jacquesa Rousseau, ani też „idiotami” w rozumieniu Philippe’a Pinela. Jednakże, mimo iż nie mają doświadczeń życiowych ani wiedzy pozostałej części gatunku homo sapiens, mają ludzki potencjał, czekający na siły tkwiące w środowisku, które będą wspierały ich dalszy rozwój ${ }^{57}$. Taką właśnie postawę zarówno badawczą, jak i pedagogiczną wykazała W. Szuman, dając wsparcie chłopcom do czasu osiągnięcia przez nich wczesnej dorosłości.

Analizowany raport z badań, studium przypadku W. Szuman zawiera interesujące konkluzje autorki. Zanim jednak badaczka do niech przechodzi, prowadzi analizy i wskazuje sytuację wejściowego potencjału dzieci, ilustruje kontekst rodzinnego wychowania w rodzinie generacyjnej, zmiany w rozwoju i funkcjonowaniu Wojtka i Leszka oraz dowody na nie w kontekście uczenia się prostych umiejętności życiowych w Pogotowiu Opiekuńczym w Toruniu i in. placówkach. W. Szuman prowadzi również $\mathrm{w}$ omawianym raporcie refleksje dotyczące fenomenu zdziczenia, nazywając je zezwierzęceniem, oraz rozważania stanu intelektualno-funkcjonalnego chłopców Wojtka i Leszka, na kontinuum fenomenów od dzikości (przywoływanych dzikich zwierząt przez kolejne osoby zaangażowane w opiekę nad dziećmi po odebraniu ich rodzicom) do człowieczeństwa. Te wątki w opracowaniu są

57 M.Ch. McNeil, E.A. Polloway, J.D. Smith, Feral and Isolated Children: Historical Review and Analysis, "Education and Training of the Mentally Retarded", 1984, Vol. 19, No. 1, p. 70-79. 
o tyle ciekawe, że wskazują interesujące dylematy badaczki oraz próby wpisania się przez nią w dyskurs naukowy odnośnie istoty człowieczeństwa, a w tym subtelnych granic semantycznie konstruowanych przez środowisko ram pojęciowych, świadczących o przynależności badanych dzieci do świata zwierząt oraz ludzi. Te wątki, jak przypuszczam, stanowią znak czasu badań lat 50-tych, związanych z fenomenem dzikich dzieci, granic ich zdziczenia oraz człowieczeństwa.

Przy okazji formułowania wniosków z projektu badawczego, W. Szuman nazwała omawiany fenomen antyedukacyjny przypadkiem działań „doprowadzania do stanu zezwierzęcenia”, a więc wychowania o wektorze odwrotnym niż rozwój i wychowanie do życia w kulturze dominującej, mimo iż badaczka nie mówi tego wprost. Wychowanie o wektorze przeciwnym oznacza wychowanie redukujące człowieczeństwo dzieci do osiągania stanu zwierzęcia i zezwierzęcenia. W. Szuman wskazała w charakterystykach dzieci te warunki, które mogły powodować myślenie o nich i postrzeganie ich w kategoriach zwierząt. Były to przede wszystkim, jak zauważam, odmienność psychosomatyczna dzieci oraz ich odrębne sposoby zachowania i komunikacji (wycie, ryki, brak umiejętności komunikacji za pomocą mowy, mimo kontaktu z ludźmi - rodzicami). Ponadto brak umiejętności siedzenia na krześle, spania w łóżku (dzieci wychodziły z łóżek, których się bały i spały na podłodze), brak umiejętności posługiwania się sztućcami (jedzenie ustami z talerzy), brak umiejętności załatwiania potrzeb fizjologicznych $\mathrm{w}$ nocniczkach lub toalecie (załatwianie się natychmiast po jedzeniu i gdzie popadnie, brudzenie pościeli). Jednocześnie badaczka wskazała istotne zmiany w rozwoju dzieci oraz ich cechy człowiecze, które bracia zaczęli silnie manifestować nawet po krótkim czasie pracy wychowawczej z nimi, w trakcie wtórnej socjalizacji i enkulturacji w latach 1955-1958. W. Szuman nakreśliła w tekście ilustracje następujących umiejętności i właściwości dzieci jako „rysy dziecięce i ludzkie”58. Badaczka kolejno wskazuje przywiązanie braci do siebie, opiekę, jaką starszy brat otaczał młodszego brata (podawanie smoczka). Ponadto fakt, że dzieci, które doświadczyły głodzenia w rodzinie generacyjnej, zaczęły się chętnie dzielić z in-

58 Tamże, s. 250. 
nymi swoim jedzeniem podczas pobytu w placówkach opiekuńczych. Szczególnie w ten sposób bracia okazywali wdzięczność ulubionym wychowawczyniom, chcąc bezpośrednio do ust wsunąć im kawałek chleba lub cukierek. Autorka kolejno wskazuje również postępy chłopców w czynnościach samoobsługowych.

Mimo pozytywnych zmian w życiu chłopców, nietrudno dojść do konkluzji, że wskazany rodzaj niepełnosprawności, indukowanej wtórnie u chłopców (urodzonych z danym potencjałem), zamanifestował się po wywołaniu go jako odmienność psychosomatyczna prowokowana. Zamysł działań rodziców był przypuszczalnie inny, lecz zilustrowany w raporcie obraz zdziczenia dzieci został osiągnięty na drodze wychowania pojętego $\mathrm{w}$ sposób fałszywy oraz doprowadzający do fałszywych wyników, czyli degradacji dzieci. Jak przypomnę, chłopcy zaczęli komunikować się werbalnie krótkimi zdaniami po około roku pedagogicznej pracy z nimi. Ponadto nauczyli się chodzić, a nie pełzać, opanowali umiejętności samoobsługowe w zakresie jedzenia sztućcami, kultury spożywania posiłków. Opanowali trening toaletowy, umiejętności zabawy. Wykazywali przywiązanie do wychowawczyń. Socjalizacja chłopców wychowywanych w skrajnej izolacji do 5. r.ż. przebiegała zdaniem W. Szuman pomyślnie, lecz jednocześnie chce wskazać, iż potencjał intelektualny predysponował chłopców do rozpoczęcia w 1957 r. kształcenia w szkole specjalnej, a nie ogólnodostępnej. Jednak tego wątku, dotyczącego potencjału intelektualnego chłopców, autorka niestety nie analizuje ani nie rozwija szerzej, ale stwierdza fakt ukończenia przez braci szkoły specjalnej.

Wśród innych konkluzji W. Szuman pojawiają się uwagi na temat środowiska sąsiedzkiego i lokalnego rodziny generacyjnej chłopców, do czasu odebrania ich rodzicom w 1954 roku. W. Szuman wskazuje w środowisku podmioty akceptujące w milczeniu dany, odmienny sposób funkcjonowania rodziny. Autorka, jak wskazałam uprzednio, uważa, że rodzice wykazywali zaangażowanie, jednak w fałszywie założonej opiece rodzicielskiej, na co przyzwalano w środowisku lokalnym. Winnych zaistniałej sytuacji dopuszczenia do stanu zezwierzęcenia dzieci badaczka postrzega w sąsiadach, którzy mieli wiedzę o tym, że rodzice nie wypuszczają dzieci z mieszkania; parafię, która mimo iż wspomagała materialnie ojca braci, nie podjęła wglądu w śro- 
dowisko życia rodziny. Ponadto pracowników ośrodka zdrowia, który znajdował się kilka domów w odległości od domu rodzinnego Wojtka i Leszka. Autorka pisze wreszcie, że szpital, w którym matka urodziła młodszego syna, „chyba też powinien był się zorientować w mentalności matki, w jej niezdolności do normalnego wychowania dzieci"59. Autorka wskazuje winnych w ówczesnym społeczeństwie, które zamyka zmysły na sytuacje nieludzkiego wychowania dzieci przez rodziców i brak korelacji instytucji, które są powołane do sprawowania pieczy nad dziećmi. Ostatnie uwagi wydają się aktualne również dzisiaj. Omawiany raport z badań wskazał implikacje do praktyki pedagogicznej pedagogiki specjalnej, reformy organizacji systemu wsparcia nad dziećmi, lecz zabrakło w nim implikacji do dalszych badań, poza wskazaniem, że jest istotne dalsze znajdowanie podobnych przypadków wychowania dzieci w izolacji.

Analiza i rekonstrukcja projektu skłania do kilku konkluzji. Moim zdaniem, przywołany, unikatowy projekt badawczy zrealizowany przez W. Szuman nakreśla ciekawą rzeczywistość istnienia silnie zaniedbanych środowisk nacechowanych skrajną izolacją, jako sposobem wychowania dzieci w Polsce lat 50-tych. Autorka wspomniała uprzednio o znanych jej łącznie 6 takich przypadkach skrajnego izolowania dzieci w całej Polsce. Chcę dodać, że omawiany raport z badań jest ilustracją unikatową w swym wymiarze, odniesioną do sytuacji prowokowania odmienności psychosomatycznej (niepełnosprawności) przez warunki kulturowe i określone niekorzystne działania rodziny generacyjnej. Można by nawet zaryzykować próbę nazwania tej mikrospołeczności sąsiedzkiej kulturą niepełnosprawności o swoistych cechach i normach funkcjonowania, wartościach oraz tabu, powodującym przyzwolenie pogłębiania się odmienności psychosomatycznej (niepełnosprawności) dzieci.

Ze względu na procesualny sposób zaistnienia niepełnosprawności dzieci, omówione studium wpisuje się w sensie psychologicznym w czynniki egzogenne niepełnosprawności intelektualnej, prowadzące do trwałych zmian w funkcjonowaniu intelektualnym i patologi-

59 Tamże, s. 254. 
zacji ich rozwoju, fenomenu, który omawia M. Kościelska ${ }^{60}$. Zmiany w rozwoju chłopców sprowokowane wielostronną deprywacją okazały się bowiem trwałe i bracia zostali uczniami szkół specjalnych. Studium przypadku przedstawione przez W. Szuman jest rzadkim przykładem skrajnie negatywnych i długotrwałych oddziaływań mikrokulturowych, generujących stan zdziczenia (odwołując się do kategorii A. Nalaskowskiego ${ }^{61}$ ) wybranych uczestników tej mikro-sceny kulturowej, społeczności lokalnej. Chcę dodać, że procesowi zdziczenia ulegali najpierw rodzice i potem cała czteroosobowa rodzina generacyjna. To, co podkreśla W. Szuman w konkluzjach, to przyzwalanie przez środowisko sąsiedzkie na degradację rodziny, ponieważ „oczy i uszy” osób z sąsiedztwa były zamknięte, co można zinterpretować istnieniem i akceptowaniem w najbliższym sąsiedztwie procesu tabuizowania odmienności rytuałów rodzinnych, podtrzymujących proces zdziczenia rodziny generacyjnej, w tym chłopców. Chcę zauważyć, że - podobnie jak socjalizacja i enkulturacja - zdziczenie jako fenomen antyedukacyjny w omawianej społeczności lokalnej, odbywało się w tym przypadku na tle konkretnej kultury dominującej lat 50-tych w Polsce.

\section{Summary}

FERAL CHILDREN' AND PROVOKED PSYCHOSOMATIC OTHERNESS.

THE RECONSTRUCTION OF THE CASE STUDY CONDUCTED BY WANDA SZUMAN (1955) CONCERNING TWO BOYS RAISED IN EXTREME ISOLATION FOR FIVE YEARS

This article reconstructs and reinterprets the unique qualitative research conducted by Wanda Szuman, an educator and andragogue specializing in special needs education from Toruń. In her research, she dealt with the development and functioning of two Polish boys defined as 'feral children'. The

60 M. Kościelska, Oblicza upośledzenia, Warszawa 1995.

61 A. Nalaskowski, Dzikość i zdziczenie jako kontekst edukacji, Kraków 2006. 
author carried out the case study and action research of the children living near Włocławek in Poland, who were confined by their parents and then taken away from them in 1954.

Keyword s: feral children, case study, psychosomatic otherness 